Management international

International Management

Gestiòn Internacional

\title{
Price Differences between Voting and Non-Voting Shares in
}

Crisis and Boom

La différence de prix entre des actions assorties d'un droit de vote et sans droit de vote en période de crise et en plein essor

\section{Diferencias de precio entre acciones con derecho a voto y acciones sin derecho a voto en períodos de crisis y auge}

Karin Niehoff et Piotr Laskowski

Volume 23, numéro hors-série, 2019

URI : https://id.erudit.org/iderudit/1068536ar

DOI : https://doi.org/10.7202/1068536ar

Aller au sommaire du numéro

\section{Éditeur(s)}

HEC Montréal

Université Paris Dauphine

ISSN

1206-1697 (imprimé)

1918-9222 (numérique)

Découvrir la revue

Citer cet article

Niehoff, K. \& Laskowski, P. (2019). Price Differences between Voting and Non-Voting Shares in Crisis and Boom. Management international/

International Management / Gestiòn Internacional, 23, 64-84.

https://doi.org/10.7202/1068536ar
Résumé de l'article

Lorsqu'une société anonyme émet des actions assorties d'un droit de vote et sans droit de vote, leur prix diffèrent normalement en raison de la valeur du droit de vote et du dividende préférentiel des actions sans droit de vote. Cette différence de prix devrait être influencée par le cycle économique. Nous analysons la différence de prix en Allemagne et en Italie entre 2003 et 2013, mais nous ne trouvons presque aucune influence. Cependant, l'influence de la structure de la propriété et de l'évolution du marché sur la différence de prix est différente en période de crise et de plein essor.
Tous droits réservés (c) Management international / International Management / Gestión Internacional, 2019
Ce document est protégé par la loi sur le droit d'auteur. L'utilisation des services d'Érudit (y compris la reproduction) est assujettie à sa politique d'utilisation que vous pouvez consulter en ligne.

https://apropos.erudit.org/fr/usagers/politique-dutilisation/ 


\section{Price Differences between Voting and Non-Voting Shares in Crisis and Boom}

\section{La différence de prix entre des actions assorties d'un droit de vote et sans droit de vote en période de crise et en plein essor}

\section{Diferencias de precio entre acciones con derecho a voto $y$ acciones sin derecho a voto en períodos de crisis y auge}

\author{
KARIN NIEHOFF \\ Department of Business Administration and Economics, \\ University of Hagen, Universitätsstraße
}

\section{ABSTRACT}

When a company issues both voting and non-voting shares, the prices are usually different, due to the value of the voting right versus the preferred dividend of the nonvoting share. This price difference may well be influenced by the business cycle. We analyze the price differences between voting and non-voting shares in Germany and Italy in different business cycles during the period 2003-2013, but find little influence attributable to the business cycle. However, the impact of the ownership structure and the market performance on the prices of voting and non-voting shares do differ in crisis and boom periods.

Keywords: voting shares, non-voting shares, value of voting right, business cycle

\author{
PIOTR LASKOWSKI \\ Keysight Technologies Germany
}

\section{RÉSUMÉ}

Lorsqu'une société anonyme émet des actions assorties d'un droit de vote et sans droit de vote, leur prix diffèrent normalement en raison de la valeur du droit de vote et du dividende préférentiel des actions sans droit de vote. Cette différence de prix devrait être influencée par le cycle économique. Nous analysons la différence de prix en Allemagne et en Italie entre 2003 et 2013, mais nous ne trouvons presque aucune influence. Cependant, l'influence de la structure de la propriété et de l'évolution du marché sur la différence de prix est différente en période de crise et de plein essor.

Mots-Clés : actions assorties d'un droit de vote, actions sans droit de vote, valeur du droit de vote, cycle économique

\section{RESUMEN}

Cuando una empresa emite acciones con derecho a voto y sin derecho a voto, los precios de ambas suelen ser diferentes. Estas diferencias en el precio pueden verse influidas por el ciclo económico. En diferentes ciclos económicos durante el período 20032013 analizamos las diferencias de precio en Alemania e Italia, pero encontramos poca influencia que pueda atribuirse al ciclo económico. Sin embargo, el impacto de la estructura de propietarios y del rendimiento del mercado sobre el precio de las acciones con derecho a voto y sin derecho a voto difiere en períodos de crisis y auge.

Palabras Clave: las participationes sociales con derecho a voto, las participationes sociales sin voto, valor de los derechos de voto, ciclo económico
$\mathrm{T}_{\mathrm{b}}^{\mathrm{b}}$ he prices of voting (or common) shares and non-voting (or preferred) shares offered by one company will differ. However differences in share prices may reflect not only the presence or absence of voting power, but also differences in dividends, in liquidity, i.e. the ease in trading the shares, or the fact that a share is exchange-traded or listed in an index. Nevertheless, many papers in our literature overview suggest that the voting premium is the main reason for the difference in share prices. Basically, there are two reasons for shareholders to desire and pay more for shares with voting rights. One is that large shareholders of voting shares are often involved in management and can achieve private benefits. They are thus willing to pay a higher share price to ensure their influence or to prevent other shareholders from acquiring a controlling stake. For example, Amoako-Adu, Smith, 2001, and Bergström, Rydqvist, 1990, argue in this way. Alternatively, a willingness to pay a voting premium could be motivated by takeover speculations; a large position in voting shares is required for a takeover. Among others Bergström, Rydqvist, 1992, and Burkart, Lee, 2008, discuss this topic in detail. Additionally, the mere possibility of a takeover can be the reason for a premium. It is worth mentioning that the above-mentioned two reasons need not be independent. The potential acquirer may pay the takeover premium only because of the private benefits he can achieve. For example, Dyck, Zingales, 2004, use the premium price of block transfers as measure for private benefits.

Many factors can influence the value of a share's voting right, i.e., the difference between the prices of voting and non-voting shares; in particular these include the ownership structure, the existence of shareholders competing for control, the possibility of achieving private benefits, or regulations concerning takeovers. Relevant studies are presented in the literature overview below.

In this article we focus on analyzing whether the difference in prices between voting and non-voting shares is influenced by the economic cycle. In particular, the crisis of 2008 and 2009 had a great impact on the economy, the values of the corporations and the prices of the shares, so we can expect that the price difference between the two types of shares is also affected. The upward trend (boom) in 2013 has also affected these prices and values. In addition, we analyze whether the development of the equity market, the ownership structure, the performance

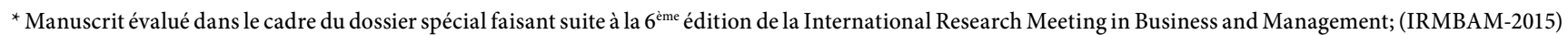
tenu les 2-3 juillet à IPAG Business School Nice - France. 
of the shares, the market value of the company, the number of non-voting shares in relation to the number of all shares, as well as the country and sector in which the company is operating in, have a different influence on the price differences depending on crisis and boom conditions. We also examine whether dividend differences between voting and non-voting shares and the takeover risk measured by the standard deviation of the free float influence the price difference.

To our knowledge, especially the effects of the business cycle and the development of the equity market have not yet been analyzed in detail. The impact of the performance of the company was analyzed by only very few authors; Kruse et al., 1993, report high relative prices for voting shares in Germany if the price difference was high. The relative price is the ratio of price and face value of a voting share. It can serve as an indicator of the performance of a firm. Similarly, Bigelli, Croci, 2013, examine the ratio of price and par value of non-voting shares. They find, contrary to Kruse et al., a negative influence on the price difference as do Cox, Roden, 2002 for the US market. The latter find high voting premiums during periods of poor firm performance and explain these results with the greater importance of the firm's policy, and thus the value of a shareholder's voting rights, in such periods.

For our analysis we chose German and Italian voting and non-voting preferred shares because these are very similar in that the non-voting shares receive a preferred dividend. In most other European countries, the shares are not really comparable to German or Italian ones. For example, Swiss preferred shares contain a voting right. The Swiss participation certificates can grant the same rights as shares except for the voting right, though this is not necessarily the case. The same is also true for France, where laws permit a wide range of possibilities. In Denmark, Finland, and Sweden there are classes of share with different numbers voting rights, but each share contains at least one voting right, so these shares are also not comparable. In some other European countries, there are no or only very few companies with listed voting and non-voting shares in the relevant time interval, so their inclusion in our analysis is not feasible. Additionally, the number of companies with exchangetraded voting and non-voting shares in Germany and Italy is not very high because an increasing number of companies unify the types of shares. We took into account all German and Italian companies with exchange-traded voting and non-voting shares in the years 2008 to 2013 . We found only 19 German and 18 Italian companies for our analysis.

With regard to the price difference between voting and non-voting shares there may be several possibly contrary considerations in play. It could be argued, for example, that the shareholder of non-voting preferred shares is less uncertain about the dividend than a shareholder of voting shares, because non-voting shares are cumulative. If a dividend cannot be paid in one year, it must be paid in subsequent years. This aspect may be more relevant in a crisis period, when the dividend payment is more uncertain than in boom periods. Furthermore, the higher dividend of a non-voting share compared to a voting share is less relevant during a boom, because the relative benefit of the non-voting share is smaller (Jung, Wachtler, 2001, p. 516; Kruse et al., 1993, p. 27; Weber et al., 1992, p. 550). On the other hand, there may be more need of participation in the decisions-makings of a firm during a crisis period (similarly, Cox, Roden, 2002, report the greater importance of a firm's policy for the shareholders when performance is poor.). Taking into account these arguments, we cannot expect the prices of voting or non-voting shares to be higher in crisis periods. During boom periods, values of firms are high, so that shareholders are able to apply their voting power to higher values than in crisis periods. We would then expect the voting shares to command higher prices than non-voting shares. Conversely, the need to control the firm may be lower in boom times than in crises periods, which would in such times lead to lower prices in voting shares than non-voting shares. Summing up, we find theoretically opposing arguments and cannot clearly expect greater price differences between voting and non-voting shares under crisis versus boom conditions.

We next analyze the price differences between voting and non-voting shares of German and Italian firms for the period 2003-2013, and compare these during crisis and boom periods. We find that the mean values of the price differences are, on average, slightly higher during the crisis than in the boom period. This indicates voting shares are valued more highly than non-voting shares during the crisis period, but these results are not at all significant. Taken altogether we can find no significant evidence that the price difference is greater or smaller, depending on the business cycle.

To gain a better insight into factors which could influence the price difference between voting and non-voting shares, we also analyze the impact of a firm's ownership structure (represented by the free float), the economic development of the market (measured by the Stoxx Europe 600), the firm's development (measured by the rate of return of the company and the value of the company), and the relevance of non-voting shares (measured by the relative non-voting capital and the relative number of non-voting shares). We control for the country and for the sector in which the company operates.

A small free float or, in other words, a high concentration of ownership is accompanied by a high price difference during our whole study period and during the crisis period. This means that where there is a high concentration of ownership, voting shares are more highly valued than non-voting shares, but that this relationship does not hold true for the boom period. The performance of the market also has a negative influence on the price difference during the whole sample period and the crisis period. Poor market performance enhances the price difference. During the boom period, the investors do not seem to pay attention to the performance of the market. The performance and the market value of a company had a positive impact on the price difference during the whole sample period, both during the crisis and the boom periods. Clearly, the shareholders want to have decision-making power in the development of firms with a high performance or a high market value. A high relative market value of the non-voting capital in relation to the market value of the company is accompanied by a small price difference in crisis and boom times. This effect is stronger in the boom year than in the crisis period. Conversely, we find a positive impact for our entire sample period. 
The remainder of this article is organized as follows. First, we provide an overview of the relevant literature. We then introduce the properties of German and Italian non-voting shares compared to voting shares, and describe their comparative values in relation to business cycle, i.e. periods of crisis and boom. Furthermore, we present theoretical arguments for why price differences between voting and non-voting shares differ in crisis and boom periods. The empirical analysis is then presented. For this analysis we use monthly data from 2003 to 2013 of pairs of voting and non-voting shares traded on German and Italian exchanges. We first compare the average price differences over the whole period and over the crisis and the boom periods. Secondly, we show the influence of the development of the whole equity market, the shareholders' structure, the performance and value of the company, the value of the non-voting capital, and the number of non-voting shares on the price difference between voting and non-voting shares. For this analysis we apply a linear regression with panel data. We control for the effect of the business cycle, and for the country and the sector in which the company operates. We repeat this regression individually for crisis and boom conditions. Finally, we take into account the change in the shareholders' structure and the differences in dividends between the types of shares. This analysis relies on yearly data, since dividends are paid yearly and variations in the shareholders' structure are also computed on a yearly basis.

\section{Literature Overview}

There are several empirical studies examining differences between voting and non-voting shares in Germany and Italy. For example Daske, Ehrhardt, 2002; Doerks, 1992; Fatemi, Krahnen, 2000; Hoffmann-Burchardi, 2000; Jung, Wachtler, 2001; Kruse et al., 1993; Reckinger, 1983; Rothauge et al., 1994; and Weber et al., 1992, present such studies concerning share price differences or the difference in rates of return for the German market. Similarly, Bigelli, Croci, 2013, Caprio, Croci, 2008, and Zingales, 1994, analyze the Italian market. In all of these studies, the authors, on average, find a positive difference between the prices of voting and non-voting shares based on different influence factors analyzed. Bigelli, Croci, 2013; Caprio, Croci, 2008; Nicodano, 1998; Daske, Ehrhardt, 2002; Fatemi, Krahnen, 2000; Jung, Wachtler, 2001; Kruse et al., 1993; and Rothauge et al., 1994, explore the influence of the ownership structure. Fatemi, Krahnen, 2000; Kruse et al., 1993, report high voting premiums for highly concentrated ownership or small free floats. It should be mentioned that they base their findings on only a small portion of the voting shares available on the market. In contrast, Jung, Wachtler, 2001, find high price differences for large free floats. They argue that a high concentration of ownership ultimately lowers the value of voting rights because concentrating holdings in a few hands hinders outside shareholders from taking part in decisions concerning the firm. Bigelli, Croci, 2013, and Rothauge et al., 1994, find no significant influence of the ownership structure. Fatemi, Krahnen, 2000, and Caprio, Croci, 2008, suggest that the type of the largest shareholder is important; in particular, family-controlled firms seem to exhibit high price differences. Nicodano, 1998, reports high voting premiums if the portion of voting shares held by outside shareholders is small. Bigelli, Croci, 2013; Jung, Wachtler, 2001; and Kruse et al., 1993, evaluate the effect of the preferred dividend; the higher the dividend difference between non-voting and voting shares, the higher is the price difference. Kruse et al., 1993, report this correlation, particularly, for poor performance of firms. Fatemi, Krahnen, 2000; Kruse et al., 1993; and Bigelli, Croci, 2013, analyze the impact on price differences of the different liquidities of the types of shares. Bigelli, Croci, 2013, can find no significant effect on the Italian market. Fatemi, Krahnen, 2000, and Kruse et al., 1993, report an influence on the price difference. The influence of legal regulations on price differences is analyzed by Caprio, Croci, 2008; Daske, Ehrhardt, 2002; Hoffmann-Burchardi, 2000; and Rothauge et al., 1994. In particular, a policy of protecting minority shareholders can reduce the price difference, because private benefits and the rights of large controlling shareholders are limited. The influence of the business cycle is not analyzed in detail in the literature. Kruse et al., 1993, find that the higher the relative price of a voting share the higher the price difference between voting and non-voting shares. The relative price is the ratio between price and face value of a share.

There are also many international studies concerning the price difference between shares with different voting rights. An overview is given by Adams, Ferraira, 2008. Similar to the above-mentioned studies, most studies reporting on other countries find a positive difference between prices of voting and non-voting shares. However, Neumann, 2003, and Odegaard, 2007, find negative differences for Denmark and Sweden. Many studies document the importance of the ownership structure for the price difference, however, their approaches in analyzing ownership structures are sometimes different. Muus, 1998, reports for France that the higher the ownership concentration, the higher is the voting premium. Cox, Roden, 2002, prove for their US sample a minimizing influence on the price difference if ownership concentration exceeds 40\%. Chung, Kim, 1999, find a positive relation between the voting premium and the control value of a block of shares held by small shareholder. Similarly, the voting power of the largest and second-largest shareholder is often considered. For example Rydqvist, 1996, shows that the voting premium is high for a company with two large shareholders of equal size. Zingales, 1995, also reports that the value of a voting right is linked to its role in a control contest. Also the type of the largest and second-largest shareholder is relevant. Muus, 1998, observes a high voting premium for family owners. Boubaker, 2007, analyzes the second largest shareholder type. Amoako-Adu, Smith, 2001, show for Canada, and DeAngelo, DeAngelo, 1985, for the US market that dualclass capitalization is often used by family firms with large controlling shareholders. Similarly, Bergström, Rydqvist, 1990, find large shareholders in companies with dual-class shares in Sweden. A "large" shareholder holds more than $50 \%$ of the high-vote shares, which receive multiple votes per share, and, additionally he holds low-vote shares with only one voting right per share. For Switzerland Schmid, 2009, observes that in dual-class firms, large shareholders are related to managerial ownership. Ang, Megginson, 1989, and Megginson, 1990, found similar trends for British shares.

Also differences between the shares are relevant. For example, Horner, 1988, and Smith, Amoako-Adu, 1996, find large price differences in Switzerland and Canada if the voting power of the registered shares is high. Conversely, Levy, 1983, finds no 
significant influence of voting power ratio for Israeli shares. He reports high differences if a calculated inequity-index is high. This index considers the relation between voting and non-voting shares with regard to the par value of the equity and the relative voting power of the shares. In France, Muus, 1988 , observes low price differences if the proportion of voting shares in relation to non-voting shares is high.

Some authors evaluate the effect of or the reason for the introduction of dual-class capitalization or of the unification of two types of shares. Cornett, Vetsuypens, 1989, find on average increasing returns for the introduction of a dual-class structure. In contrast, Jarrell, Poulsen, 1988, report negative abnormal returns when a dual-class recapitalization is announced. A finding by Partch, 1987, is somewhat weaker; she maintains that shareholders are not harmed by dual-class recapitalization. These articles focus on the US market but cover different periods. Amoako-Adu, Smith, 2001, report different reasons for share-type unifications, for example, the planned sale of a control block. Pajuste, 2005, reports an increase in firm value with a unification of types of shares.

Some authors discuss the impact of legal regulations on the price difference. Neumann, 2003, shows that regulations protecting minority shareholder decreases price differences between voting and non-voting shares. Nenova, 2003, analyzes several countries. Instead of the difference between prices she takes into account the value of the control block; this value varies among countries and is dependent on legal regulations like investors' protection or takeover rules.

\section{Voting and Non-Voting Shares in Germany and Italy}

German and Italian law allows companies to issue voting and non-voting shares. In Germany the law prescribes a priority dividend for non-voting shares, meaning that a company must pay the priority dividend before paying any dividend to the shareholders of the voting shares. Hence the non-voting shares are always preferred shares. In Germany there is no regulation concerning the amount of the priority dividend, so it can be very small (Hüffer, 2012, $\$ 139$ AktG, No. 7). Additionally, the priority dividend must be cumulative. If the priority dividend is not or not fully paid in one year, the company must pay it in subsequent years. If the priority dividend is not paid in one year and cannot be paid fully the next year, the shareholders of non-voting preferred shares receive the right to vote until the priority dividends of all previous years have been paid. Furthermore, non-voting shares may receive higher dividends than voting shares. In Italy the law also prescribes a priority dividend, the concrete privileges being set by the company's charter (Bigelli, Croci, 2013). Many Italian companies still follow an expired law prescribing a priority dividend to non-voting shares, a higher dividend for non-voting shares if a dividend is paid to the voting shares and a payment of arrears of the last two years, if no dividends were paid to the non-voting shares. Unlike with German non-voting shares, Italian non-voting shares can never receive voting rights. Altogether, we find that Italian and German non-voting shares are very similar.

In Germany and Italy, the value of non-voting shares is strongly linked to that of the voting shares. There are, however, two factors that affect their value relationship. On the one hand, because the dividend of non-voting shares may be higher than that from voting shares, the value of non-voting shares, all else being equal, will also be higher. On the other hand, the voting shareholders have a voting right. If the power to vote is valuable, then the value of voting shares may c.-p. be higher. These two considerations may offset each other with regard to the relative value of voting or non-voting shares.

\section{Business Cycle and Price Differences}

In our analysis we define "the crisis" as the years 2008 and 2009. An important event was the bankruptcy of Lehman Brothers which took place in September 2008. In the following months the prices of shares measured by the Stoxx Europe 600, a European stock index of large, mid-size and small capitalization companies of the European region, declined dramatically. A decline in the index before the bankruptcy of Lehman Brothers could already be observed beginning in October 2007 and continuing until February 2009. If we compare the values of the index in 2009 to those of the preceding year there is actually a decline until September 2009. Furthermore, business cycles are often defined by the gross domestic product. The quarterly values of the GDP for 12 European countries (source: Eurostat) declined from the third quarter of 2008 to the fourth quarter of 2009 compared to the values of the preceding year.

In our analysis, the year 2013 is defined as a boom period. Unlike during the crisis of 2008-2009, there was a relatively continuous increase in the Stoxx Europe 600 in 2013, especially, if we compare that year to the preceding one. The gross domestic product began to increase starting in the second quarter of 2013.

Some theoretical arguments can explain the price difference between voting and non-voting shares during boom and crisis periods. The dividend of the non-voting shares is higher than or at least as high as that for voting shares. Some companies pay the same dividend to voting and non-voting shares if any dividend is paid, but the non-voting shares may receive a dividend during a downturn in the business cycle, even if voting shares do not. If no dividends are paid to non-voting shares, the company must pay the preferred dividend in subsequent years; this is not the case for voting shares. We expect the price of non-voting shares to be higher than for voting shares if the difference between their dividends is large. Furthermore, the difference in dividends between voting and non-voting shares, if it exists, may be less important in boom periods because both types of share receive high dividends. If we only take dividends into account, the hypothesis holds that higher prices are paid for non-voting shares than for voting shares in the crisis periods.

The value of the voting right is mainly driven by the takeover premium and the possibility of realizing private benefits. These aspects are not independent since takeovers might take place to generate private benefits. If companies are more valuable in boom than in crisis times, larger private benefits are probable. One would thus expect the value of voting rights to be higher in boom than in crisis periods. Moreover, private benefits aside, the value of a company itself is higher during a boom. If a company is taken over during a boom, it is more valuable; thus, the value of the shareholders' voting rights is also likely to be higher. On the other hand, there may be more need for 
control in a crisis period, motivating shareholders to place a higher value on voting power at such times. Conversely, because of operational constraints in times of economic downturn, it might be thought that there is little need of decision-making at such times, rendering voting power of less interest. If this is the logic, then decision-making is more possible and thus more attractive in boom times, rendering voting rights more valuable. Such pro-and-con arguments affect the voting premium in often contrary directions. The question thus remains regarding how price differences empirically develop in crisis and boom periods.

Many other factors, in conjunction with the economic cycle of boom and crisis, may influence the price difference between shares with and without voting rights. In particular, we analyze whether the development of the market, the value and performance of a company, its ownership structure, its number of voting shares, and its value of the non-voting capital exert different effects on the price of voting and non-voting shares in crisis and boom periods. We would expect the development of the market and the performance of the company to show a high correlation. The development of the market is represented here by Stoxx Europe 600 and the performance of the company by the rate of return on its shares and the value of the company. If there is more need of shareholder control in poor situations like crises, an increase in the Stoxx Europe 600 or in the performance of the company should be accompanied by a decrease of the price difference between voting and non-voting shares. However, if we expect more shareholder interest in voting rights and decision-making in boom times, an increase in these factors should increase price difference.

Ownership structure also affects the value of voting rights. In particular, shareholders competing for control can give rise to a high value being placed on voting power. If there is a high free float, expressed as a percentage value of all voting shares, then the value of voting rights should be small because there are no large shareholders competing for control. We expect this relationship to be valid in both crisis and boom periods.

Another relevant consideration is the number of non-voting shares in relation to the number of all shares. If there are many non-voting shares - or, expressed differently, only a few voting shares - then the right to vote represents more power over the shared capital of the company and is therefore more valuable. In such cases, the value of a voting share is high in relation to non-voting shares. This should hold true in both crisis and boom periods. Similarly, a high non-voting capital in relation to the value of the company should be accompanied by a high value of the voting share.

We now turn to the interrelation between the risk of a takeover and the price difference between voting and non-voting shares. A takeover is possible if a shareholder purchases a large number of shares or if block transfers take place. These situations are often accompanied by changes in the free float. Thus variations in the free float are an indicator for risk of a takeover. Since, a large takeover risk puts a high premium on voting shares we can expect a positive relationship between the standard deviation of the free float and the voting premium.

\section{Data and Approach}

Our study focuses on companies with exchange-listed voting and non-voting shares in 2013 . We identified 19 German and 18 Italian companies with available price data. A list of the analyzed companies and the exchanges is given in Table 1 in the Appendix. In the following text, the names of the companies are used without the legal form. The price data was taken from Thomson Reuters' Datastream. We have data covering the whole time span for all companies except Telecom Italia, Telecom Italia Media, Dyckerhoff, Eurokai, and Fresenius Medical Care. For Telecom Italia and Telecom Italia Media, the time series start in August 2003 and for Eurokai in May 2007. The time series of Dyckerhoff ends in August 2013 and of Fresenius Medical Care in July 2013.

The price differences between the voting and non-voting shares are calculated on a monthly basis (with end-of-month courses) and are represented either as an absolute or relative difference. The relative difference is related to the price of the non-voting shares in percent. In the following text, capital letters represent absolute and lowercase relative values.

$$
\begin{aligned}
& \left.\Delta P_{t, n}=P_{t, n, V}-P_{t, n, N V} \quad \text { [Euro }\right] \\
& \Delta p_{t, n}=\frac{P_{t, n, V}-P_{t, n, N V}}{P_{t, n, N V}} \cdot 100 \quad[\%]
\end{aligned}
$$

$\mathrm{P}_{t, n, V}$ is the price of the voting share of the $\mathrm{n}$-th company at the end of the $\mathrm{t}$-th month and $\mathrm{P}_{t, n, N V}$ the appropriate price of the non-voting share. The higher the price difference, the more expensive are the voting shares in relation to the non-voting shares. The end-of-month differences are computed for each company. The absolute price difference is an indicator for the voting right per share and the relative price difference for the voting right per Euro invested in a share.

Four companies (Banca Carrige, Saipem, Stefanel, and Volkswagen) exhibit very high, partially negative differences. These data would dominate all results. We therefore discarded these companies leaving 18 German and 15 Italian companies in our data set with 4279 observations.

We calculate the price differences and their means for the whole period (2003-2013), the crisis (2008-2009), and the boom (2013) for every company.

Additionally, we compute a mean over all companies for the three time intervals. We compare the means during crisis and boom periods and apply a t-test to analyze the significance of the results. The t-test in small samples requires normally distributed data, which we cannot prove for our data set. But the t-test is usually robust to non-normality. Because of the small sample, we additionally use the non-parametric Wilcoxon rank-sum test to confirm our results.

We next analyze the influence of the free float of voting shares, of the Stoxx Europe 600, of the rate of return on voting shares, of the market value of the company, of the relative market value of the non-voting capital, of the relative number of the non-voting shares, and of the country and sector in which the company operates on the price difference, using a linear regression with panel data. From Thomson Reuters' 
Datastream we took the data on free float, Stoxx Europe 600, market value of the company, value of the non-voting capital, and the number of shares. Because the data on the free float of Effecten-Spiegel starts in January 2008, we have to reduce our data set, accordingly. We also take the data on sectors from Thomson and Reuters'; the subdivision is based on Worldscope.

The free float $\left(\mathrm{ff}_{t, n, V}\right)$ of the voting shares provided by Thomson Reuters' is a relative value and represents the percentage of voting shares available to ordinary investors. Holdings of more than $5 \%$ are not included. This variable is an indicator of concentrated shareholding. $\mathrm{ff}_{t, n, V}$ is the free float of the $\mathrm{t}$-th month and $\mathrm{n}$-th company, and Stoxx 600 is a European stock index of large, mid-size and small capitalization companies of the European region, which we use to describe the development of the market.

In our regression we also use the monthly rates of return of the $\mathrm{t}$-th month and the $\mathrm{n}$-th company $\left(\right.$ return $\left._{t, n, V}\right)$ calculated by the following formula:

$$
\text { return }_{t, n, V}=\frac{P_{t, n, V}-P_{t-1, n, V}}{P_{t-1, n, V}} \cdot 100 \quad[\%]
$$

The performance of a company is measured by this return.

The market value $\left(\right.$ Value $\left._{t, n}\right)$ is the sum of the values of all shares of a company. We compute the relative market value of the non-voting shares $\left(\right.$ value $_{t, n N \text { V }}$ ) by dividing the non-voting capital by the total capital of the company.

$$
\text { value }_{t, n, N V}=\frac{\text { Value }_{t, n N N}}{\text { Value }_{t, n}} \cdot 100 \quad[\%]
$$

Value $_{t, n, N V}$ is the value of the non-voting capital of the t-th month and the n-th company.

In our regression we also use the relative number of nonvoting shares $\left(n o_{t, n, N V}\right)$ calculated by the following formula:

$$
n o_{t, n, N V}=\frac{N O_{t, n, N V}}{N O_{t, n, N V}+N O_{t, n, V}} \cdot 100 \quad[\%]
$$

$N O_{t, n, N V}$ is the number on non-voting shares in the $\mathrm{t}$-th month for the $\mathrm{n}$-th company. Similarly, $\mathrm{NO}_{t, n, V}$ is the number of voting shares.

We considered the countries in the regression with a dummy; the value for Italian companies is one, and otherwise zero. Additionally we added two dummies for "boom" and "crisis". The sectors are "industry", "utility", "transportation”, "bank, savings and loans", and "other financial services". We apply dummies to add these sectors into the regression.

In addition to the panel data regression of the overall sample period we provide panel data regressions for the crisis and boom periods individually. Finally, we apply a panel data regression with yearly data to evaluate the effect of dividends of the companies and the standard deviation of the free float on the price differences in the whole period. We cannot consider the dividend differences and the standard deviation of the free float in the first panel data regressions since this data is not monthly, while all other data is. We also take the dividends from Thomson Reuters' Datastream and use the relative dividend difference $\left(\Delta\right.$ dividend $\left._{T, n}\right)$ in our regression

$$
\Delta \text { dividend }_{T, n}=\frac{\text { Dividend }_{T, n, N V}-\text { Dividend }_{T, n, V}}{P_{T, n, N V}} \cdot 100 \quad[\%]
$$

Dividend $_{T, n, N V}$ and Dividend ${ }_{T, n, V}$ are the yearly dividends of the non-voting and voting shares of the n-th company and T-th year, and $P_{T, n, N V}$ is the average price of the non-voting share in the T-th year.

The yearly standard deviation of the free float $\left(S t d_{-} f_{T, n, V}\right)$ is computed using the monthly values of a year. It illustrates the variations in the free float or vice versa in concentrated holdings. Frequent and great changes in the percentage free float indicate a risk of concentrated holding and thus the risk of a takeover.

\section{Relative and Absolute Price Differences Between Voting and Non-voting Shares in Crisis AND Boom}

The means of the relative and absolute price differences of each company for the whole period, and for the crisis and the boom periods are given in Table 2. Because the relative difference is the variable used most, we show the median, maximum and minimum value, and the standard deviation for the whole period in Table 3 in the Appendix.

For the following analysis we will usually consider the relative price difference. The average absolute difference may be dominated by results of companies with high price differences.

The means of the relative price differences for the whole period, and for the crisis and boom periods are positive. For the crisis period, the mean is higher than for the boom year, i.e. the value of the voting shares in relation to the non-voting shares is on average higher in the crisis period than in the boom period. Through the whole period only five out of 33 companies exhibit negative mean price differences. In the crisis and the boom there are eight average negative price differences in each case. Out of 33 companies, 24 show a higher average price difference in the crisis than in the boom period. The average value of the means is $28.84 \%$ in the crisis and $22.26 \%$ in the boom. Thus during the crisis, the average price difference is $6.58 \%$ higher than in the boom year. This means that, compared to the non-voting shares, the values for the voting shares are higher in the crisis than in the boom period. This could be interpreted as a slightly higher value of the voting right in the crisis. Nevertheless, we adopt a paired t-test to analyze the significance. The results are not significant at any common level $(\mathrm{t}(32)=0.9959, \mathrm{p}=0.3268)$. We can therefore summarize that there is no significant difference between the price differences in the crisis and those in the boom period. This finding is underlined by the Wilcoxon rank-sum test. The $\mathrm{z}$-value is 0.891 , which shows that there is no significant difference. The probability that the price difference is higher in the crisis period is $56.40 \%$. This leads to the conclusion that the value of the voting right is not significantly influenced by crisis and boom conditions. Furthermore, we could observe this result individually for both, Germany and Italy.

To compute the relative price difference, we divide the absolute price difference by the price of the non-voting share. If we assume that this price is low in the crisis and high in the boom the result for the relative price differences could be caused by the division. We therefore have to analyze the absolute price differences. The average absolute price difference is 4.28 Euro 
in the crisis and 2.65 Euro in the boom. Thus the prices of the voting shares are 1.63 Euro higher in the crisis than in the boom period. The results for the relative price difference do not only rely on the calculation of the values.

Additionally, we calculate the means of the company-individual relative (7) and absolute (8) price differences for every month.

$$
\begin{aligned}
\Delta \bar{p}_{t} & =\sum_{n=1}^{N} \Delta p_{t, n} / N \\
\Delta \bar{P}_{t} & =\sum_{n=1}^{N} \Delta P_{t, n} / N
\end{aligned}
$$

The development is illustrated in Figure 1. It does not document a high or low price difference in the crisis or boom months. There seems to be a decreasing tendency throughout the entire period and an increasing tendency of relative price differences in the crisis period. In the boom year there are varying - but neither increasing nor decreasing - price differences.

We can sum up by saying that the different effects of crisis and boom conditions almost cancel each other out. We might observe a tendency towards larger price differences in the crisis period because of shareholders' desire to exert more control in harder economic times.

\section{TABLE 2}

Average absolute (Euro) and relative (\%) price differences between voting and non-voting shares for every company for the entire sample period from 2003 to 2013, the crisis from 2008 to 2009 and the boom in 2013. The relative price difference is calculated by dividing

\begin{tabular}{|c|c|c|c|c|c|c|}
\hline \multirow[b]{2}{*}{ Company } & \multicolumn{3}{|c|}{ Absolute price difference (Euro) } & \multicolumn{3}{|c|}{ Relative price difference (\%) } \\
\hline & Entire period & Crisis & Boom & Entire period & Crisis & Boom \\
\hline Ahlers & 0.0822 & 0.6171 & 0.0695 & 1.6833 & 9.8234 & 0.7878 \\
\hline BancoDi Desio & 0.3241 & 0.1915 & 0.0765 & 9.0746 & 4.0992 & 4.0270 \\
\hline Biotest & 3.3708 & 4.0244 & 3.1644 & 15.5345 & 10.0201 & 5.6804 \\
\hline BMW & 11.0457 & 7.6925 & 19.2667 & 34.7816 & 40.1217 & 34.6850 \\
\hline Borgosesia & 0.2477 & -0.0431 & -0.1653 & 20.3325 & -2.0171 & -14.9064 \\
\hline Buzzi Unicem & 4.3168 & 4.4440 & 5.6746 & 61.9547 & 61.4302 & 92.8069 \\
\hline Danieli & 5.2642 & 5.7954 & 7.2208 & 63.6169 & 64.9639 & 52.7625 \\
\hline Dyckerhoff & 3.5802 & 0.5825 & -0.0200 & 16.9474 & 1.5819 & 0.1016 \\
\hline Effecten-Spiegel & 2.0735 & 0.9321 & 0.7742 & 16.3047 & 8.6550 & 6.3499 \\
\hline Eurokai & 0.7500 & 0.4479 & 0.1317 & 6.2163 & 5.5975 & 0.7961 \\
\hline Fresenius Medical Care & 4.7598 & 1.7367 & 4.5250 & 18.7816 & 5.5544 & 10.3104 \\
\hline Fuchs-Petrolub & -1.3368 & 0.8895 & -7.6238 & -1.1803 & 7.9116 & -12.1222 \\
\hline Henkel & -4.7334 & -2.8900 & 11.2358 & -11.5755 & -11.0249 & -15.1454 \\
\hline Intek Group & 0.0217 & -0.1625 & -0.0688 & 0.5486 & -28.1410 & -18.1150 \\
\hline Intesa Sanpaolo & 0.4190 & 0.5164 & 0.2478 & 21.5026 & 25.8747 & 19.8230 \\
\hline Italmobiliare & -9.0107 & -7.8029 & -2.3417 & -27.8927 & -29.0255 & -20.9032 \\
\hline KSB & 22.5173 & 32.7950 & 30.2208 & 8.9853 & 10.9395 & 6.8479 \\
\hline MAN & 7.4630 & 0.2458 & 1.0825 & 16.1632 & 2.8763 & 1.2714 \\
\hline Metro & -0.3636 & 5.1392 & 3.2171 & 2.5423 & 15.2374 & 12.5132 \\
\hline Mineralbrunnen Ueberkingen Teinach & 8.0089 & 10.1071 & 8.2692 & 97.7373 & 151.4245 & 111.1579 \\
\hline Montefibre & -0.0743 & -0.0346 & -0.0908 & -27.3588 & -14.4749 & -54.7637 \\
\hline Pirelli \& C. & 0.7153 & -0.1179 & 2.6900 & 12.7018 & -3.0978 & 39.5474 \\
\hline RWE & 5.6292 & 10.8978 & 1.3650 & 12.0997 & 19.6773 & 5.4675 \\
\hline SAES Getters & 2.8946 & 1.6767 & 0.6313 & 35.0822 & 21.3730 & 9.9257 \\
\hline Salini Impreglilo & -4.4352 & -5.3940 & -9.6137 & -60.1999 & -74.4973 & -73.4863 \\
\hline Sartorius & 1.0399 & 3.1033 & 2.4767 & 11.9638 & 32.9608 & 3.0550 \\
\hline Sixt & 2.6922 & 1.7156 & 2.9188 & 25.8883 & 21.8749 & 18.2926 \\
\hline Telecom Italia & 0.3184 & 0.2996 & 0.1147 & 25.8752 & 35.5285 & 22.9302 \\
\hline Telecom Italia Media & 0.3310 & 0.1979 & 0.3119 & 81.7628 & 31.9181 & 162.5112 \\
\hline Unicredit & 68.3585 & 57.9534 & 15.3852 & 372.5706 & 351.8110 & 297.7689 \\
\hline Vincenzo Zucchi & 0.5212 & 0.3216 & 0.0068 & 150.1922 & 140.8737 & 3.6786 \\
\hline Westag\& Getalit & 0.1238 & -0.0929 & -0.0379 & 5.9405 & -0.3798 & -0.2030 \\
\hline WMF & 4.8427 & 5.5563 & 8.7618 & 23.9283 & 32.1175 & 21.0226 \\
\hline Mean & 4.2957 & 4.2831 & 2.6486 & 31.5911 & 28.8360 & 22.2568 \\
\hline
\end{tabular}
the absolute difference by the price of the non-voting share. 


\section{FIGURE 1}

Average monthly absolute and relative price differences between voting and non-voting shares. The relative price difference was computed by dividing the absolute price difference by the price of the non-voting share. The left ordinate shows the values of the absolute price difference and the right one of the relative price difference.

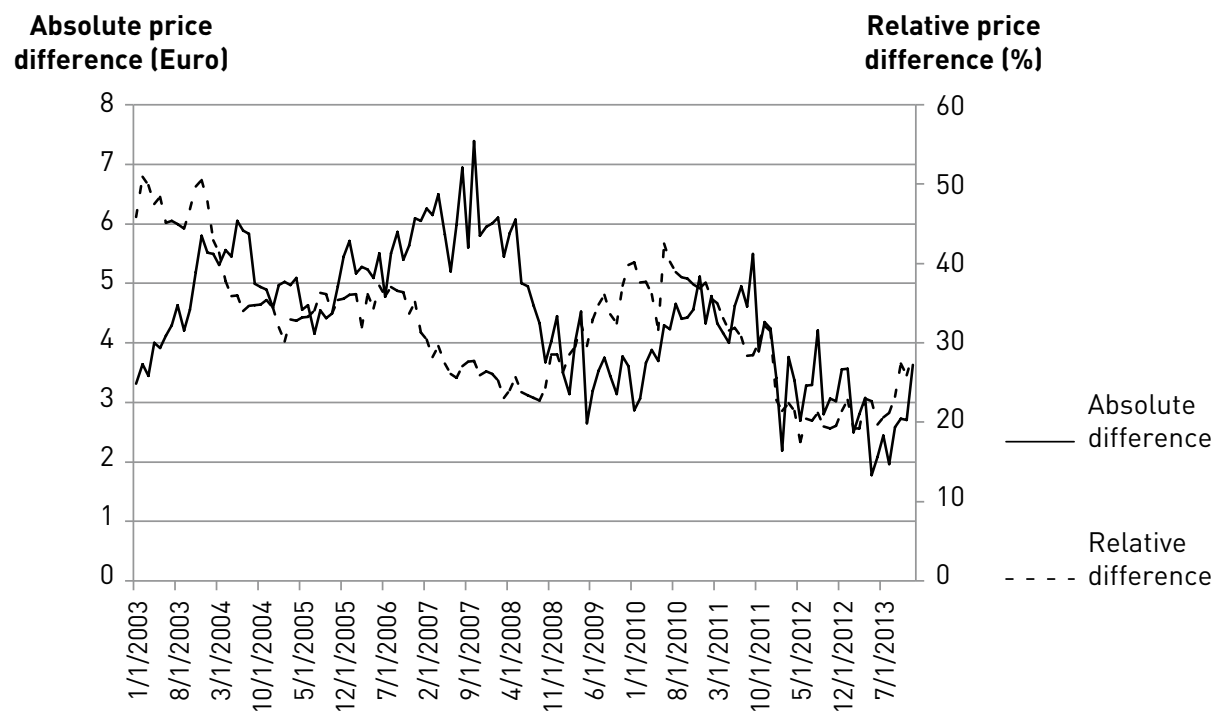

\section{Panel Data Regression - the Influence of Different Factors in the Overall Sample Period}

Firstly, we run a linear regression with panel data for the entire period. The dependent variable is the monthly relative price difference and the independent variables are the free float percentage of the voting shares ( $\left.\mathrm{ff}_{t, n, V}\right)$; the Stoxx Europe 600 (Stoxx $)$; the monthly rates of return on the voting shares (return ${ }_{t, n, V}$ ); the market value of the company (Value ${ }_{t, n}$ ); the relative market value of the non-voting capital (value ${ }_{t, n, N V}$ ); and the number of non-voting shares in relation to all shares issued by a company $\left(n o_{t, n, N V}\right)$. Furthermore, we add a dummy for the countries (Country). The value of the dummy is one for Italian companies and zero otherwise. In a similar way, we consider two dummies for the crisis period (Crisis) and boom period (Boom). Additionally, we add four dummies for the sectors in which the companies operate (Industry, Utility, Transportation, Banks). The value is one, if the company is part of the sector, and zero if it is not. Since Thomson Reuters' did not document the number of shares for Effecten-Spiegel until 2008, we discarded the missing observations; 4219 observations are considered in the regression.

A regression delivers only meaningful results if the correlations of the independent variables are not too high. The correlation matrix is documented in Table 4 in the Appendix. Because the correlation of value ${ }_{t, n, N V}$ and $n o_{t, n, N V}$ is very high, we discard $n o_{t, n, N V}$. Furthermore, we calculate the variance inflation factors (VIF) to check for multicollinearity. The results are given in Table 5 in the Appendix.

The regression equation is:

$$
\begin{aligned}
& \Delta p_{t, n}=\beta_{0}+\beta_{1} \cdot f f_{t, n, V}+\beta_{2} \cdot \text { Stoxx }_{t}+\beta_{3} \cdot \text { return }_{t, n, V} \\
& +\beta_{4} \cdot \text { Value }_{t, n}+\beta_{5} \cdot \text { value }_{t, n, N V}+\beta_{6} \cdot \text { Country }+\beta_{7} \\
& \cdot \text { Crisis }+\beta_{8} \cdot \text { Boom }+\beta_{9} \cdot \text { Industry }+\beta_{10} \cdot \text { Utility }+\beta_{11} \\
& \cdot \text { Transportation }+\beta_{12} \cdot \text { Banks }+\varepsilon_{t, n}
\end{aligned}
$$

The outcome of the regression is presented in Table 6.

The regression shows that the relative market value of the non-voting capital, the country and the sector have no significant influence on the relative price difference between voting and non-voting shares.

The effect of the free float is significant and negative. This means that the smaller the percentage of voting shares traded freely, the higher is the relative price difference. This relationship could be expected. The smaller the free float - or in other words the higher the concentrated ownership - the higher the value of the voting right will be. The voting right is more valuable if there are only a few owners with a large proportion of shares that are not traded freely. The finding that the value of the voting right decreases with increasing free float is in accordance with Fatemi, Krahnen, 2000, and Kruse et al., 1993. However Daske, Erhard, 2002, report a high value for the voting right with a medium level of ownership concentration and a low value for both high and low concentrations.

The coefficient of the Stoxx 600 is also significant and negative. The relative price difference is high when the whole market performs poorly. This may be an indicator of greater price differences in the crisis situation, because market performance is negatively correlated with the dummy for the crisis. This would underline the finding of the cross sectional analysis which states that there is a higher need for control in crisis than in boom situations.

The performance of the voting shares measured by the rate of return on voting shares has a significant positive effect on the relative price difference. If a company shows high performance, the value of the voting right is also high. This finding is contrary to the results of Cox, Roden, 2002, who report a high voting premium if the company is performing poorly. In our 
sample there is a high voting premium if company performance is high. This effect is probably not caused by different returns over time but is distinct to certain companies. Companies with high returns exhibit higher values for voting rights. When a company shows high returns it is important to decide on these returns in crisis and boom periods.

The influence of the value of the company is also positive. A high firm value is accompanied by a high relative price difference. Analysis indicates that large companies are characterized by highly valued voting rights.

The effects of boom and crisis on relative price differences are both negative - meaning that the difference is small in both the boom and crisis periods, as compared to the whole sample. At the first glance, this result is surprising. We pointed out above a tendency towards a decreasing price difference over time. The sample without the boom and crisis times covers the years 2003 to 2007 and 2010 to 2011, so it represents mainly the first half of the analyzed time span. This can explain the negative coefficients of crisis and boom parts of the sample. The coefficient of the boom is higher in absolute values than that of the crisis. The value of the price difference - or in other words the value of the voting right - is therefore smaller in the boom months than in the crisis period. This result confirms our statements resulting from the cross sectional analysis.

\section{Panel Data Regression - The Influence of Different Factors in Crisis and Boom}

In the panel data regression we have so far analyzed the effects on price differences of several factors over the entire sample period. To compare these to the effects on price differences during boom and crisis periods, we apply a panel regression separately for each. The correlations of the independent variables are documented in Table 7 and 8 in the Appendix. Furthermore, we calculate the variance inflation factors (VIF) to check for multicollinearity. The results are given in Table 9 in the Appendix.

\section{TABLE 6}

Panel data regression for the entire sample period: The regression equation is

$$
\begin{aligned}
\Delta p_{t, n}= & \beta_{0}+\beta_{1} \cdot f f_{t, n, V}+\beta_{2} \cdot \text { Stoxx }_{t}+\beta_{3} \cdot \text { return }_{t, n, V}+\beta_{4} \cdot \text { Value }_{t, n}+\beta_{5} \cdot \text { value }_{t, n, N V}+\beta_{6} \cdot \text { Country } \boldsymbol{\beta}_{7} \cdot \text { Crisis } \\
& +\boldsymbol{\beta}_{8} \cdot \text { Boom }+\boldsymbol{\beta}_{9} \cdot \text { Industry }+\boldsymbol{\beta}_{10} \cdot \text { Utility }+\boldsymbol{\beta}_{11} \cdot \text { Transportation }+\boldsymbol{\beta}_{12} \cdot \text { Banks }+\varepsilon_{t, n}
\end{aligned}
$$

The monthly relative price differences between the voting and non-voting shares are the dependent variable. The independent variables are the monthly values of the free float, the Stoxx Europe 600, the monthly market values of the companies, the monthly relative market values of the non-voting capital, and dummies for the country, the crisis and boom periods, and the different sectors industry, utility,

\begin{tabular}{|c|c|}
\hline Independent variable & Coefficient (z-value) \\
\hline Intersept & $\begin{array}{l}0.5065 \\
(0.93)\end{array}$ \\
\hline Free float (ff) & $\begin{array}{c}-0.2650 * * * \\
(-6.36)\end{array}$ \\
\hline Stoxx 600 (Stoxx) & $\begin{array}{c}-0.0011 * * * \\
(-8.20)\end{array}$ \\
\hline Return on the voting shares (return) & $\begin{array}{c}0.2948 * * * \\
(4.77)\end{array}$ \\
\hline Value of the company (Value) & $\begin{array}{c}0.000011^{* * *} \\
(9.96)\end{array}$ \\
\hline Relative market value of non-voting capital (value) & $\begin{array}{l}0.1068 \\
(0.63)\end{array}$ \\
\hline Country & $\begin{array}{c}0.1929 \\
(0.69) \\
\end{array}$ \\
\hline Crisis & $\begin{array}{c}-0.0703^{* * *} \\
(-4.26)\end{array}$ \\
\hline Boom & $\begin{array}{c}-0.0945^{* * *} \\
(-4.32)\end{array}$ \\
\hline Industry & $\begin{array}{c}-0.0149 \\
(-0.03)\end{array}$ \\
\hline Utility & $\begin{array}{l}-0.2181 \\
(-0.30)\end{array}$ \\
\hline Transportation & $\begin{array}{l}0.0646 \\
(0.09)\end{array}$ \\
\hline Banks & $\begin{array}{l}0.8661 \\
(1.26) \\
\end{array}$ \\
\hline $\mathrm{R}^{2}$ (overall) & 0.1936 \\
\hline Observations & 4219 \\
\hline
\end{tabular}
transportation, and banks.

${ }^{*}$ significant at the $10 \%$ level, ${ }^{* *}$ significant at the $5 \%$ level, ${ }^{* * *}$ significant at the $1 \%$ level 
Taking into account the values of the correlations and the variance inflation factors we can apply a panel data regression. For the crisis sample, we do not include the relative number of voting shares because of the high correlation of this factor with the market value of the non-voting capital. For the boom sample, we apply two panel data regressions, the first with the data we use for the crisis. In this way we can compare the coefficients precisely. Second, we add the relative number of non-voting shares because the correlation with the relative non-voting capital is not so high as to prohibit a regression.

The regression equations for crisis and boom conditions are identical, however they rely on different periods. They are also similar to the regression equation for the entire period, only the dummies for crisis and boom are withdrawn.

$$
\begin{aligned}
\Delta p_{t, n} & =\beta_{0}+\beta_{1} \cdot f f_{t, n, V}+\beta_{2} \cdot \text { Stoxx }_{t}+\beta_{3} \cdot \text { return }_{t, n, V} \\
& +\beta_{4} \cdot \text { Value }_{t, n}+\beta_{5} \cdot \text { value }_{t, n, N V}+\beta_{6} \cdot \text { Country } \\
& +\beta_{7} \cdot \text { Industry }+\beta_{8} \cdot \text { Utility }+\beta_{9} \cdot \text { Transportation } \\
& +\beta_{10} \cdot \text { Banks }+\varepsilon_{t, n}
\end{aligned}
$$

Additionally, we use the following equation for the boom; in comparison to equation (10) the relative number of voting shares is added as an independent variable:

$$
\begin{aligned}
\Delta p_{t, n} & =\beta_{0}+\beta_{1} \cdot f f_{t, n, V}+\beta_{2} \cdot \text { Stoxx }_{t}+\beta_{3} \cdot \text { return }_{t, n, V} \\
& +\beta_{4} \cdot \text { Value }_{t, n}+\beta_{5} \cdot \text { value }_{t, n, N V}+\beta_{6} \cdot \text { no }_{t, n, N V} \\
& +\beta_{7} \cdot \text { Country }+\beta_{8} \cdot \text { Industry }+\beta_{9} \cdot \text { Utility } \\
& +\beta_{10} \cdot \text { Transportation }+\beta_{11} \cdot \text { Banks }+\varepsilon_{t, n}
\end{aligned}
$$

The results of the regressions are given in Table 10, 11 and 12.

The coefficient of the percentage free float is negative and significant in crisis times, similar to the overall sample period, though the level of significance is less. However, in boom times it is not significant at all. We showed that the relative price difference is, on average potentially smaller in boom than in crisis periods, when the concentration of voting rights may also not be relevant. We can therefore conclude that the influence of the free float on the value of the voting right differs in crisis and boom times.

\section{TABLE 10}

\begin{tabular}{|c|c|}
\hline Intersept & $\begin{array}{c}1.0873^{* *} \\
(2.00)\end{array}$ \\
\hline Free float (ff) & $\begin{array}{c}-0.3676^{* *} \\
(-2.40)\end{array}$ \\
\hline Stoxx 600 (Stoxx) & $\begin{array}{c}-0.0010 * * * \\
(-4.40)\end{array}$ \\
\hline Return on the voting shares (return) & $\begin{array}{c}0.1539 * \\
(1.94)\end{array}$ \\
\hline Value of the company (Value) & $\begin{array}{c}.00002^{* * *} \\
(8.22)\end{array}$ \\
\hline Relative market value of the non-voting capital (value) & $\begin{array}{c}-2.0174^{* * *} \\
(-4.96)\end{array}$ \\
\hline Country & $\begin{array}{c}-0.1714 \\
(-0.61)\end{array}$ \\
\hline Industry & $\begin{array}{l}0.0153 \\
(0.03)\end{array}$ \\
\hline Utility & $\begin{array}{c}-0.5867 \\
(-0.81)\end{array}$ \\
\hline Transportation & $\begin{array}{l}0.3511 \\
(0.48)\end{array}$ \\
\hline Banks & $\begin{array}{l}0.3184 \\
(0.47)\end{array}$ \\
\hline $\mathrm{R}^{2}$ (overall) & 0.1314 \\
\hline Observations & 792 \\
\hline
\end{tabular}

Panel data regression for the crisis period: The regression equation is

$\Delta p_{t, n}=\beta_{0}+\beta_{1} \cdot f f_{t, n, V}+\beta_{2} \cdot$ Stoxx $_{t}+\beta_{3} \cdot$ return $_{t, n, V}+\beta_{4} \cdot$ Value $_{t, n}+\beta_{5} \cdot$ value $_{t, n, N V}+\beta_{6} \cdot$ Country $\boldsymbol{\beta}_{7} \cdot$ Industry

$+\beta_{8} \cdot$ Utility $+\beta_{9} \cdot$ Transportation $+\beta_{I 0} \cdot$ Banks $+\varepsilon_{t, n}$

The monthly relative price differences are the dependent variable. The independent variables are the monthly values of the free float, the Stoxx Europe 600, the monthly values of the companies, the monthly relative market values of the non-voting capital, and dummies for the country and the different sectors industry, utility, transportation, and banks.

Independent variable

${ }^{*}$ significant at the $10 \%$ level, ${ }^{* *}$ significant at the $5 \%$ level, ${ }^{* * *}$ significant at the $1 \%$ level 
The effect of the performance of the market measured by the Stoxx 600 is negative in the crisis sample. This result is in line with the results for the entire sample period. We can find no significant influence of market performance in the boom period. The value of the voting rights also does not react systematically to variations in the Stoxx 600 in the boom year. Hence we could say that the voting right is not relevant in times of a good market performance.

The performance of the company measured by the rate of return on the voting shares has a positive influence on the relative price difference in the entire sample period, as well as in the crisis and boom periods. Only the level of significance is different. It is highest for the entire sample and lowest for the boom months. Thus the previous statement regarding the entire period can also be applied to the crisis and boom periods as well. The coefficients do not differ substantially, so there are no remarkable differences between crisis and boom samples with regard to company performance. This finding underlines our previous findings in which voting rights are highly valued for companies with good performance, regardless of the analyzed period. Considering the regression with equation (11), we no longer find any significant influence of company performance on the value of the voting right. Clearly, the impact of "relative number of shares" suppresses the impact of "return on the voting shares".
In crisis and boom periods, we find a positive coefficient for the market value of a company. The above findings for the entire sample period hold true for crisis and boom periods separately. Altogether our findings confirm that companies with high performance exhibit a high value for voting rights, regardless of the sample period considered.

Though the coefficient for the relative market value of the non-voting capital was not significant for the overall sample period, it is negative and significant for both the crisis and boom periods. The higher the relative value of the non-voting capital, and consequently the lower the value of the relative voting capital, the smaller is the difference between prices of voting and non-voting shares. The coefficients do not differ considerably, so there is no discrepancy between crisis and boom periods.

The coefficients of the dummies for "Country" and for the sectors remain insignificant for both crisis and boom periods - like for the entire period.

Our analysis of the relative number of non-voting shares in the boom period results in a positive and significant coefficient for this factor. The more non-voting shares issued by a company the fewer voting rights there will be in relation to total capital - and the more asymmetrically distributed the voting and

\section{TABLE 11}

Panel data regression for the boom period: The regression equation is

$\Delta p_{t, n}=\beta_{0}+\beta_{1} \cdot f f_{t, n, V}+\beta_{2} \cdot$ Stoxx $_{t}+\beta_{3} \cdot$ return $_{t, n, V}+\beta_{4} \cdot$ Value $_{t, n}+\beta_{5} \cdot$ value $_{t, n, N V}+\beta_{6} \cdot$ Country $\boldsymbol{\beta}_{7} \cdot$ Industry

$+\beta_{8} \cdot$ Utility $+\beta_{9} \cdot$ Transportation $+\beta_{10} \cdot$ Banks $+\varepsilon_{t, n}$

The monthly relative price differences are the dependent variable. The independent variables are the monthly values of the free float, the Stoxx Europe 600, the monthly values of the companies, the monthly relative market values of the non-voting capital, and dummies for the country and different sectors industry, utility, transportation, and banks.

\begin{tabular}{|l|c|}
\hline Independent variable & Coefficient (z-value) \\
\hline Intersept & 0.3115 \\
& $(0.56)$ \\
\hline Free float (ff) & -0.0577 \\
& $(-0.58)$ \\
\hline Stoxx 600 (Stoxx) & 0.0003 \\
& $(0.57)$ \\
\hline Return on the voting shares (return) & $0.1526^{*}$ \\
& $(1.70)$ \\
\hline Value of the company (Value) & $0.00004^{* * *}$ \\
& $(7.21)$ \\
\hline Relative market value of the non-voting capital (value) & $-1.7670^{* * *}$ \\
& $(-4.18)$ \\
\hline Country & 0.0652 \\
& $(0.23)$ \\
\hline Industry & -0.0153 \\
& $(-0.03)$ \\
\hline Utility & -0.4682 \\
& $(-0.66)$ \\
\hline Transportation & 0.4103 \\
\hline Banks & $(0.57)$ \\
\hline R loverall) & 0.1061 \\
\hline Observations & $(0.16)$ \\
\hline
\end{tabular}

${ }^{*}$ significant at the $10 \%$ level, ${ }^{* *}$ significant at the $5 \%$ level, ${ }^{* * *}$ significant at the $1 \%$ level 
capital rights will be. This leads to more highly valued voting rights. A simultaneous consideration of the market value of the non-voting capital and the relative number of voting shares in the regression produces a higher squared $\mathrm{R}$, but the coefficient of the return on the voting shares is no longer significant.

\section{The Influence of Dividend Payments and TAKEOVER RISK}

The absolute dividends of the voting versus the non-voting shares are less important than the relative difference between the dividends earned by non-voting and voting shares. We calculate this relative difference in dividends by dividing the absolute difference between the dividends of the non-voting and voting shares by the average price of the non-voting share in the respective year. The data for the calculation was taken from Thomson Reuters'. There are no dividend data available for Telecom Italia in 2003. Also, we take the yearly standard deviation of the percentage of free float voting shares into account. Furthermore, we consider the average yearly values of all independent variables of the previous regressions. Table 13 in the Appendix documents the correlations between the potential independent factors of the panel regression. Since the relative market value of the non-voting capital and the relative number of non-voting shares exhibit a high correlation, we consider only the market value of the voting shares. Furthermore, we calculate the variance inflation factors (VIF) to check for multicollinearity. The factors of the relative market value of the non-voting capital and the relative number of non-voting shares are very high. Thus we repeat the test without the relative number of non-voting shares. The results are given in Table 14 in the Appendix.

The equation of the panel data regression is:

$$
\begin{aligned}
& \Delta p_{T, n, \text { rel }}=\beta_{0}+\beta_{1} \cdot \Delta \text { dividend }_{T, n, V}+\beta_{2} \cdot \text { Std } f f_{T, n, V}+\beta_{3} \\
& \cdot \mathrm{ff}_{T, n, V}+\beta_{4} \cdot \text { Stoxx }_{T}+\beta_{5} \cdot \text { return }_{T, n, V}+\beta_{6} \cdot \text { Value }_{T, n} \\
& +\beta_{7} \cdot \text { value }_{T, n, N V}+\beta_{8} \cdot \text { Country }+\beta_{9} \cdot \text { Crisis } \\
& +\beta_{10} \cdot \text { Boom }+\beta_{11} \cdot \text { Industry }+\beta_{12} \cdot \text { Utility } \\
& +\beta_{13} \cdot \text { Transportation }+\beta_{42} \cdot \text { Banks }+\varepsilon_{T, n}
\end{aligned}
$$

The results of the regression are shown in Table 15.

\section{TABLE 12}

Panel data regression for the boom period: The regression equation is

$\Delta p_{t, n}=\beta_{0}+\beta_{1} \cdot f f_{t, n, V}+\beta_{2} \cdot$ Stoxx $_{t}+\beta_{3} \cdot$ return $_{t, n, V}+\beta_{4} \cdot$ Value $_{t, n}+\beta_{5} \cdot$ value $_{t, n, N V}+\beta_{6} \cdot$ no $_{t, n, N V}+\beta_{7} \cdot$ Country

$+\beta_{8} \cdot$ Industry $+\beta_{9} \cdot$ Utility $+\beta_{10} \cdot$ Transportation $+\beta_{11} \cdot$ Banks $+\varepsilon_{t, n}$

The monthly relative price differences are the dependent variable. The independent variables are the monthly values of the free float, the Stoxx Europe 600, the monthly values of the companies, the monthly relative market values of the non-voting capital, the monthly relative values of the number of non-voting shares, and dummies for the country and the different sectors industry, utility, transportation, and banks.

\section{Independent variable}

Intersept

Free float (ff)

Stoxx 600 (Stoxx)

Return on the voting shares (return)

Value of the company (Value)

Relative market value of the non-voting capital (value)

Relative number of non-voting shares (no)

Country

Industry

Utility

Transportation

Banks

\begin{tabular}{|l|c|} 
& 0.2619 \\
\hline & $(0.42)$ \\
\hline $\mathrm{R}^{2}$ loverall) & 0.1829 \\
\hline Observations & 385 \\
\hline
\end{tabular}

${ }^{*}$ significant at the $10 \%$ level, ${ }^{* *}$ significant at the $5 \%$ level, ${ }^{* * *}$ significant at the $1 \%$ level
Coefficient (z-value)

$-0.1170$

$(-0.22)$

$-0.0472$

$(-0.47)$

0.0003

(0.57)

0.1208

(1.33)

$0.00004^{* * *}$

(7.41)

$-2.3660 * * *$

$(-4.93)$

1.8857***

(2.75)

0.2483

(0.92)

$-0.0157$

$(-0.03)$

$-0.4034$

(-0.61)

0.2781

(0.41)

0.2619

0.2619

(0.42)

385 


\section{TABLE 15}

Panel data regression for the entire sample period: The regression equation is

$\Delta p_{T, n}=\beta_{0}+\beta_{1} \cdot$ sdividend $_{T, n, V}+\beta_{2} \cdot$ Std $_{f f} f_{T, n, V}+\beta_{3} \cdot f f_{T, n, V}+\beta_{4} \cdot$ Stoxx $_{T}+\beta_{5} \cdot$ return $_{T, n, V}+\beta_{6} \cdot$ Value $_{T, n}+\beta_{7} \cdot$ value $_{T, n, N V}$ $+\beta_{8} \cdot$ Country $+\beta_{9} \cdot$ Crisis $+\beta_{10} \cdot$ Boom $+\beta_{11} \cdot$ Industry $+\beta_{12} \cdot$ Utility $+\beta_{13} \cdot$ Transportation $+\beta_{42} \cdot$ Banks $+\varepsilon_{T, n}$

The yearly average relative price differences are the dependent variable. The independent variables are the yearly average values of the monthly free float, of the monthly Stoxx Europe 600, of the monthly values of the companies, of the monthly relative values of the non-voting capital, and dummies for the country, the crisis and boom periods, and the different sectors industry, utility, transportation, and banks.

\begin{tabular}{l|r} 
Independent variable & Coefficient (z-value)
\end{tabular}

\begin{tabular}{|c|c|}
\hline Intersept & $\begin{array}{c}0.4992 \\
(1.19)\end{array}$ \\
\hline Relative dividend difference ( $\Delta$ dividend) & $\begin{array}{c}-5.0024^{* * *} \\
(-5.92)\end{array}$ \\
\hline Standard deviation of the free float (Std_ff) & $\begin{array}{r}0.0921 \\
(0.29)\end{array}$ \\
\hline Free float (FF) & $\begin{array}{c}-0.2114 \\
(-1.34) \\
\end{array}$ \\
\hline Stoxx 600 (Stoxx) & $\begin{array}{c}-0.0011^{* *} \\
(-2.29)\end{array}$ \\
\hline Return on the voting shares (return) & $\begin{array}{c}-0.0241 \\
(-0.03)\end{array}$ \\
\hline Value of the company (Value) & $\begin{array}{c}6.86 \mathrm{e}-06^{*} \\
(1.77)\end{array}$ \\
\hline Relative value of the non-voting capital (value) & $\begin{array}{l}0.0107 \\
(0.03) \\
\end{array}$ \\
\hline Country & $\begin{array}{c}0.2184 \\
(1.13)\end{array}$ \\
\hline Crisis & $\begin{array}{c}-0.0555085 \\
(-0.94)\end{array}$ \\
\hline Boom & $\begin{array}{c}-0.0817 \\
(-1.15)\end{array}$ \\
\hline Industry & $\begin{array}{l}0.0362 \\
(0.10) \\
\end{array}$ \\
\hline Utility & $\begin{array}{r}-0.1017 \\
(-0.21) \\
\end{array}$ \\
\hline Transportation & $\begin{array}{c}0.0879 \\
(0.18)\end{array}$ \\
\hline Banks & $\begin{array}{l}0.7318 \\
(1.59)\end{array}$ \\
\hline $\mathrm{R}^{2}$ (overall) & 0.3686 \\
\hline Observations & 353 \\
\hline
\end{tabular}

${ }^{*}$ significant at the $10 \%$ level, ${ }^{* *}$ significant at the $5 \%$ level, ${ }^{* * *}$ significant at the $1 \%$ level

The standard deviation of the free float of voting shares has no significant influence on the price difference between voting and non-voting shares. Hence the takeover risk as measured by the variation in the concentration of holdings is not relevant for the voting premium.

The relative difference in the dividends between voting and non-voting shares is quite important. The coefficient is significantly negative and the squared $\mathrm{R}$ of the model increases remarkably. The higher the relative dividend of the non-voting share, the smaller is the relative price difference - or in other words the higher will be the price of the non-voting share in relation to the price of the voting share. This finding is not related to the voting right itself, but to the usually higher dividend of a non-voting share. Aside from the coefficient of the dividend difference, only the coefficients of the Stoxx 600 and of the market value of the company are significant. The influence of these variables on the relative price difference does not change in comparison to the previous analyses. We cannot apply a panel analysis to crisis and boom periods individually because we do not have enough data specifically for the boom.

\section{Limitations of the Analysis}

Since an increasing number of companies unify non-voting and voting shares, there are just a few companies with exchangetraded voting and non-voting shares in Germany and Italy. Furthermore, it is problematic to add more countries to this kind of analysis because preferred or non-voting shares in other European countries are not sufficiently comparable. These limitations make it difficult to generalize our findings. 


\section{Conclusion}

This paper analyses the price differences between the voting and non-voting shares of companies in Germany and Italy in two different business cycles, i.e. in the crisis period defined as the years 2008 and 2009 and in the boom period defined as the year 2013. In our sample, the voting shares are on average valued slightly higher in relation to the non-voting shares in the crisis period than in the boom year. It is probable that decisions by voting shareholders are more important in times of crisis than in boom periods. However, this trend is not significant there is almost no difference between crisis and boom periods with regard to the value of voting rights. Nevertheless, some factors do have different effects on the price difference in crisis and boom periods. Whether there is a high free float of the voting shares or shareholding is concentrated in a few hands does play a role, in our crisis period, though not in the boom year. The value of voting rights in the crisis period is found to be high if the free float is small. The performance of the market measured by the Stoxx 600 is also relevant in the crisis months and not relevant in the boom period. The higher the index the lower is the voting premium. Furthermore, high company performance and a high value of the company are accompanied by a high value for voting rights in the crisis situation as well as in the boom. Particularly the shareholders of highly valued and high-performing companies desire the right to decide on questions regarding their company. Higher dividends paid to the non-voting shares compared to dividends to voting shares result in high prices for non-voting shares.

\section{References}

Adams, Renée; Ferreira, Daniel (2008). "One share - one vote: the empirical evidence," Review of Finance, Vol. 12, № 1, p. 51-91.

Амодко-Adu, Ben; Sмiтh, Brian F. (2001). "Dual class firms: capitalization, ownership structure and recapitalization back into single class," Journal of Banking and Finance, Vol. 25, $\mathrm{N}^{\circ} 6$, p. 1083-1111.

Ang, James S.; Megginson, William L. (1989). "Restricted voting shares, ownership structure, and the market value of dual-class firms," Journal of Financial Research, Vol. 12, $\mathrm{N}^{\circ} 4$, p. 301-318.

Bergström, Clas; Rydqvist, Kristian (1990). "Ownership of equity in dual-class firms, "Journal of Banking and Finance, Vol. 14, No 2/3, p. 255-269.

BergströM, Clas; Rydqvist, Kristian (1992). "Differentiated bids for voting and restricted voting shares in public tender offers," Journal of Banking and Finance, Vol. 16, № 1, p. 97-114.

Bigelli, Marco; Croci, Ettore (2013). "Dividend privileges and the value of voting rights: Evidence from Italy," Journal of Empirical Finance, Vol. 24, p. 94-107.

BoubAKer, Sabri (2007). "Ownership-control discrepancy and firm value: evidence from France," Multinational Finance Journal, Vol. 11, № 3/4, p. 211-252.

Burkart, Mike; Lee, Samuel (2008). “The one share - one vote debate: the theory," Review of Finance, Vol. 12, No 1, p. 1-49.

CAPrio, Lorenzo; Croci, Ettore (2008). "The determinants of the voting premium in Italy: The evidence from 1974 to 2003," Journal of Banking and Finance, Vol 32, № 11, p. 2433-2443.
Chung, Kee H.; Kim, Jeong-Kuk (1999). "Corporate ownership and the value of a vote in an emerging market," Journal of Corporate Finance, Vol. 5, No 1, p. 35-54.

Cornett, Marcia Millon; Vetsuy pens, Michael R. (1989). “Voting rights and shareholder wealth, the issuance of limited voting common stock," Managerial and Decision Economics, Vol. 10, No 3, p. 175-188.

Cox, Steven R.; Roden, Dianne M. (2002). "The Source of value of voting rights and related dividend promises," Journal of Corporate Finance, Vol. 8, № 4, p. 337-351.

DAske, Stefan; Ehrhardt, Olaf (2002). „Kursunterschiede und Renditen deutscher Stamm- und Vorzugsaktien, “Financial Markets and Portfolio Management, Vol. 16, №2, p. 179-207.

DeAngelo, Harry; DeAngelo, Linda (1985). “Managerial ownership of voting rights: a study of public corporations with dual classes of common stock," Journal of Financial Economics, Vol. 14, No 1, p. 33-69.

Doer Ks, Wolfgang (1992). Der Kursunterschied zwischen StammVorzugsaktien in der Bundesrepublik Deutschland, Köln: Müller Botermann Verlag, 349 p.

Dyck, Alexander; Zingales, Luigi (2004). "Private benefits of control: an international comparison," Journal of Finance, Vol. 59, No 2, p. 537-600.

Eurostat, quarterly national accounts, GDP and main components, namp_10_gdp, http://ec.europa.eu/eurostat/web/nationalaccounts/data/main-tables.

Fatemi, Ali; Krahnen, Jan P. (2000). "On the valuation of common and preferred shares in Germany: new evidence on the value of voting rights," Managerial Finance, Vol. 26, № 10, p. 42-54.

Hoffmann-Burchardi, Ulrike (2000). “Corporate governance rules and the value of control - a study of German dual-class shares," Discussion paper 315, London School of Economics, Financial Markets Groups.

Horner, Melchior R. (1988). "The value of the corporate voting right: evidence from Switzerland," Journal of Banking and Finance, Vol. 12, № 1, p. 69-83.

HüFfER, Uwe (2012). Beck'sche Kurzkommentare, Band 53, Aktiengesetz, 10th ed., Munich: Beck-Verlag.

Jarrell, Gregg A.; Poulsen, Annette B. (1988). "Dual-class recapitalizations as antitakeover mechanisms, the recent evidence," Journal of Financial Economics, Vol. 20, No 1/2, p. 129-152.

Jung, Axel; WaChTLER, Frank (2001). „Die Kursdifferenz zwischen Stamm-und Vorzugsaktien. Empirische Daten, Erklärungsansätze und Konsequenzen für die Bewertung im Steuer- und Gesellschaftsrecht," Die Aktiengesellschaft, Vol. 46, No 10 , p. 513-520.

Kruse, Hermann; Berg, Erik; Weber, Martin (1993). „Erklären unternehmensspezifische Faktoren den Kursunterschied von Stamm- und Vorzugsaktien?" Zeitschrift für Bankrecht und Bankwirtschaft, Vol. 5, № 1, p. 23-31.

LEvy, Haim (1983). "Economic evaluation of voting power of common stock," Journal of Finance, Vol. 38, № 1, p. 79-93.

Megginson, William L. (1990). "Restricted voting shares, acquisition premiums, and the market value of corporate control," Financial Review, Vol. 25, № 2, p. 175-198. 
Muus, Christian K. (1998). "Non-voting shares in France: an empirical analysis of the voting premium," Working paper series: Finance \& Accounting, Johann Wolfgang GoetheUniversität Frankfurt a. M., № 22.

Nenova, Tatiana (2003). "The value of corporate voting rights and control: a cross-country analysis," Journal of Financial Economics, Vol. 68, No 3, p. 325-351.

Neumann, Robert (2003). "Price differentials between dual-class stocks: voting premium or liquidity discount?," European Financial Management, Vol. 9, No 3, p. 315-332.

NiCODANO, Giovanna (1998). Corporate groups, dual-class shares and the value of voting rights,"Journal of Banking and Finance, Vol. 22, No 9, p. 1117-1137.

OdegaARD, Bernt A. (2007). "Price differences between equity classes. Corporate control, foreign ownership or liquidity," Journal of Banking \& Finance, Vol. 31, № 12, p. 3621-3645.

Pajuste, Anete (2005). "Determinants and consequences of the unification of dual-class shares," Working paper series European Central Bank, № 465.

PARTCH, M. Megan (1987). „The creation of a class of limited voting common stock and shareholder wealth," Journal of Financial Economics, Vol. 18, № 2, p. 313-339.

Reckinger, Gabriele (1983). „Vorzugsaktien in der Bundesrepublik,“ Die Aktiengesellschaft, Vol. 28, № 8, p. 216-222.
Rothauge, Frank A.; Menkhoff, Lukas; Krahnen, Jan P. (1994). „Erklärt Übernahmespekulation die Preisbildung von Vorzugsaktien?“ Die Bank, No 4, p. 239-244.

RYDQVIST, Kristian (1996). "Takeover bids and the relative prices of shares that differ in their voting rights," Journal of Banking and Finance, Vol. 20, № 8, p. 1407-1425.

Schmid, Markus M. (2009). "Ownership structure and the separation of voting and cash flow rights - evidence from Switzerland," Applied Financial Economics, Vol. 19, № 18, p. 1453-1476.

Smith, Brian F.; Амоако-Adu, Ben (1996). "Relative prices of dual class shares," Journal of Financial and Quantitative Analysis, Vol. 30, No 2, p. 223-239.

Weber, Martin; Berg, Erik; Kruse, Hermann (1992). „Kurs- und Renditevergleich von Stamm- und Vorzugsaktien," Schmalenbachs Zeitschrift für betriebswirtschaftliche Forschung, Vol. 44, No 6, p. 548-565.

ZINGALES. Luigi (1994). “The value of the voting right: a study of the Milan stock exchange experience," Review of Financial Studies, Vol. 7, № 1, p. 125-148.

ZiNGALES, Luigi (1995). "What determines the value of corporate votes?," Quaterly Journal of Economics, Vol. 110, No 4, p. 1047-1073. 


\section{ANNEXES \\ TABLE 1}

Analyzed companies, country the company headquarters, and stock exchange used for the empirical analyses

\begin{tabular}{|c|c|c|}
\hline Company & Country & Stock Exchange \\
\hline Ahlers AG & Germany & Frankfurt \\
\hline Banca Carige S.p.A. & Italy & Milan \\
\hline Banco Di Desio E Della Brianza S.p.A. & Italy & Milan \\
\hline Biotest AG & Germany & Xetra \\
\hline BMW AG & Germany & Xetra \\
\hline Borgosesia S.p.A. & Italy & Milan \\
\hline Buzzi Unicem S.p.A. & Italy & Milan \\
\hline Danieli S.p.A. & Italy & Milan \\
\hline Dyckerhoff $A G^{1}$ & Germany & Xetra \\
\hline Effecten-Spiegel AG & Germany & Stuttgart \\
\hline Eurokai GmbH \& Co. KGaA ${ }^{2}$ & Germany & $\begin{array}{c}\text { Hanover (voting) } \\
\text { Frankfurt (non-voting) }\end{array}$ \\
\hline Fresenius Medical Care AG \& Co. KGaA & Germany & Xetra \\
\hline Fuchs-Petrolub AG & Germany & Xetra \\
\hline Henkel AG \& Co. KGaA & Germany & Xetra \\
\hline Intek Group S.p.A. & Italy & Milan \\
\hline Intesa Sanpaolo S.p.A. & Italy & Milan \\
\hline Italmobiliare S.p.A. & Italy & Milan \\
\hline KSB AG & Germany & Xetra \\
\hline MAN SE & Germany & Xetra \\
\hline Metro AG & Germany & Xetra \\
\hline Mineralbrunnen Überkingen-Teinach AG & Germany & Frankfurt \\
\hline Montefibre S.p.A. & Italy & Milan \\
\hline Pirelli \& C. S.p.A. & Italy & Milan \\
\hline RWE AG & Germany & Xetra \\
\hline SAES Getters S.p.A. & Italy & Milan \\
\hline Saipem S.p.A. & Italy & Milan \\
\hline Salini Impregilo S.p.A. & Italy & Milan \\
\hline Sartorius AG & Germany & Xetra \\
\hline Sixt SE & Germany & Xetra \\
\hline Stefanel S.p.A. & Italy & Milan \\
\hline Telecom Italia S.p.A. ${ }^{4}$ & Italy & Milan \\
\hline Telecom Italia Media S.p.A. ${ }^{5}$ & Italy & Milan \\
\hline Unicredit S.p.A. & Italy & Milan \\
\hline Vincenzo Zucchi S.p.A. & Italy & Milan \\
\hline Volkswagen AG & Germany & Xetra \\
\hline Westag \& Getalit AG & Germany & Xetra \\
\hline WMF Württembergische Metallwarenfabrik AG & Germany & Xetra \\
\hline
\end{tabular}

1 Squeeze-out in August 2013; data available until July 2013.

2 Data available from May 2007 onwards.

3 Non-voting shares converted to voting shares in 2013; data available until July 2013.

4, 5 Data available from August 2003 onwards. 


\section{TABLE 3}

Mean, median, maximum and minimum value, and standard deviation of the relative price difference (\%) for the entire sample period from 2003 to 2013. The relative price difference is calculated by dividing the absolute difference by the price of the non-voting share.

\begin{tabular}{|c|c|c|c|c|c|}
\hline Company & Mean & Median & Maximum value & Minimum value & Standard deviation \\
\hline Ahlers & 1.6833 & 0.0000 & 27.5862 & -7.2193 & 6.1105 \\
\hline BancoDi Desio & 9.0746 & 5.1469 & 54.1183 & -34.3348 & $13.086 \mathrm{dc} 2$ \\
\hline Biotest & 15.5345 & 9.8200 & 52.0410 & 0.9582 & 12.4073 \\
\hline BMW & 34.7816 & 40.2215 & 67.8737 & -0.2045 & 16.6745 \\
\hline Borgosesia & 20.3325 & -5.1057 & 247.4175 & -56.8285 & 66.4817 \\
\hline Buzzi Unicem & 61.9547 & 56.0478 & 112.4004 & 6.4765 & 24.4475 \\
\hline Danieli & 63.6169 & 60.2268 & 97.8169 & 29.2683 & 18.9535 \\
\hline Dyckerhoff & 16.9474 & 5.4067 & 83.3568 & -6.9286 & 21.6449 \\
\hline Effecten-Spiegel & 16.3047 & 9.6116 & 51.6428 & -1.9155 & 14.1872 \\
\hline Eurokai & 6.2163 & 3.5016 & 55.3191 & -15.8096 & 12.2156 \\
\hline Fresenius Medical Care & 18.7816 & 18.2392 & 47.8618 & -0.5672 & 13.5319 \\
\hline Fuchs-Petrolub & -1.1803 & -3.9891 & 77.1899 & -15.9228 & 10.9188 \\
\hline Henkel & -11.5755 & -10.9087 & -3.8596 & -19.1089 & 4.4052 \\
\hline Intek Group & 0.5486 & -7.4260 & 132.0523 & -57.2180 & 42.4311 \\
\hline Intesa Sanpaolo & 21.5026 & 20.4259 & 52.9380 & 3.2016 & 11.9262 \\
\hline Italmobiliare & -27.8927 & -28.3895 & -13.1029 & -40.7117 & 6.8782 \\
\hline KSB & 8.9853 & 6.6463 & 49.7754 & -5.9761 & 10.8548 \\
\hline MAN & 16.1632 & 10.0136 & 64.3137 & -20.7706 & 19.5909 \\
\hline Metro & 2.5423 & 0.3320 & 56.3003 & -40.0000 & 24.4632 \\
\hline Mineralbrunnen Ueberkingen Teinach & 97.7373 & 89.8882 & 227.7228 & 13.0303 & 43.8211 \\
\hline Montefibre & -27.3588 & -22.7671 & 11.4754 & -76.4706 & 23.4114 \\
\hline Pirelli \& C. & 12.7018 & 6.0216 & 78.7419 & -20.9507 & 21.6844 \\
\hline RWE & 12.0997 & 11.1907 & 42.5541 & 0.1550 & 6.2261 \\
\hline SAES Getters & 35.0822 & 29.8464 & 87.3207 & -0.2366 & 20.1452 \\
\hline Salini Impreglilo & -60.1999 & -66.6513 & -18.6860 & -84.0454 & 20.2323 \\
\hline Sartorius & 11.9638 & 4.3752 & 148.9063 & -17.9487 & 23.5795 \\
\hline Sixt & 25.8883 & 25.0910 & 59.3137 & 0.7595 & 10.8452 \\
\hline Telecom Italia & 25.8752 & 23.7332 & 59.4030 & 7.9306 & 10.4180 \\
\hline Telecom Italia Media & 81.7628 & 53.3786 & 307.0588 & -16.6261 & 81.2190 \\
\hline Unicredit & 372.5706 & 415.7466 & 493.0374 & 98.8535 & 100.9834 \\
\hline Vincenzo Zucchi & 150.1922 & 109.3042 & 677.7778 & -33.2548 & 142.7065 \\
\hline Westag \& Getalit & 5.9405 & 0.0000 & 216.3333 & -25.6823 & 33.7878 \\
\hline WMF & 23.9283 & 22.5215 & 67.0025 & 4.5918 & 10.5533 \\
\hline
\end{tabular}




\section{TABLE 4}

Correlations of the following independent variables: free float of the voting shares ( $f f_{t, y}$ ), Stoxx Europe 600 (Stoxx $)$, performance of the voting shares (return $\left.{ }_{t, y}\right)$, market value of the company (Value ${ }_{t, n}$ ), relative market value of the non-voting capital (value tnvv $_{\text {) }}$, relative number of the voting shares ( $n_{t, n v}$ ), and the dummies for the country (Country), the crisis period (Crisis), the boom period (Boom), and the sectors Industry (Industry), Utility (Utility), Transportation (Transportation), Banks, savings and loans (Banks) used in the panel data regression covering the entire sample period. The variables are monthly values.

\begin{tabular}{|l|c|c|c|c|c|c|c|c|} 
& \multicolumn{1}{|c|}{ ff } & Stoxx & Return & Value & value & no & Country & \\
\hline ff & 1.0000 & & & & & & \\
\hline Stoxx & -0.0098 & 1.0000 & & & & & \\
\hline return & -0.0295 & 0.0154 & 1.0000 & & & & \\
\hline Value & 0.4712 & 0.1439 & -0.0096 & 1.0000 & & & & \\
\hline value & -0.3820 & -0.0083 & 0.0361 & -0.3475 & 1.0000 & & & \\
\hline no & -0.3929 & -0.0263 & 0.0495 & -0.3520 & 0.9695 & 1.0000 & & \\
\hline Country & 0.1716 & 0.0108 & -0.0525 & 0.0251 & -0.4439 & -0.4175 & 1.0000 & \\
\hline Crisis & 0.0005 & -0.2517 & -0.1001 & -0.0102 & 0.0026 & 0.0021 & -0.0110 & 1.0000 \\
\hline Boom & -0.0410 & 0.1746 & 0.0252 & -0.0068 & 0.0130 & -0.0001 & 0.0010 & -0.1523 \\
\hline Industry & 0.4008 & 0.0019 & 0.0451 & -0.4078 & 0.1987 & 0.1873 & -0.1692 & -0.0214 \\
\hline Utility & 0.3328 & 0.0109 & -0.0263 & 0.4350 & -0.0957 & -0.0797 & 0.0104 & -0.0006 \\
\hline Transport. & 0.0186 & 0.0010 & 0.0020 & -0.1151 & 0.1496 & 0.1647 & -0.2149 & 0.0228 \\
\hline Banks & 0.2523 & 0.0001 & -0.0258 & 0.4272 & -0.3038 & -0.3102 & 0.3445 & -0.0049 \\
\hline
\end{tabular}

\begin{tabular}{|l|c|c|c|c|c|}
\hline & Boom & Industry & Utility & Transport. & Banks \\
\hline Boom & 1.0000 & & & & \\
\hline Industry & -0.0198 & 1.0000 & & & \\
\hline Utility & 0.0019 & -0.4372 & 1.0000 & & \\
\hline Transport. & 0.0175 & -0.3948 & -0.0586 & 1.0000 & \\
\hline Banks & -0.0004 & -0.5525 & -0.0820 & -0.0740 & 1.0000 \\
\hline
\end{tabular}

\section{TABLE 5}

Variance inflation factor (VIF) of the following independent variables: free float of the voting shares (ff $f_{t, n v}$ ), Stoxx Europe 600 (Stoxx $)_{t}$, performance of the voting shares $\left(r_{t} t_{u r n} n_{t, y}\right)$, market value of the company $\left(V_{a l u e_{t, n}}\right)$, relative market value of the non-voting capital (value ${ }_{\text {. }}$ ), relative number of the voting shares $\left(n_{t, n v}\right)$, and the dummies for the country (Country), the crisis period (Crisis), the boom period (Boom), and the sectors Industry (Industry), Utility (Utility), Transportation (Transportation), Banks, savings and loans (Banks) used in the panel data regression covering the entire sample period. The variables are monthly values.

\begin{tabular}{|l|l|}
\hline & VIF \\
\hline Stoxx & 1.60 \\
\hline return & 1.14 \\
\hline Value & 1.02 \\
\hline value & 2.23 \\
\hline no & 1.20 \\
\hline Country & 1.55 \\
\hline Crisis & 1.61 \\
\hline Boom & 1.10 \\
\hline Industry & 1.05 \\
\hline Utility & 4.52 \\
\hline Transport. & 2.72 \\
\hline Banks & 2.05 \\
\hline Mean VIF & 3.40 \\
\hline
\end{tabular}




\section{TABLE 7}

Correlations of the following independent variables: free float of the voting shares $\left(f_{t, n, v}\right.$ ), Stoxx Europe 600 (Stoxx $x_{t}$, performance of the voting shares ( return $\left._{t, n, V}\right)$, market value of the company (Value $\left.e_{t, n}\right)$, relative market value of the non-voting capital (value ${ }_{t, n, N v}$ ), relative number of the voting shares ( ${ }_{t, n, N v}$ ), and the dummies for the country (Country), and the sectors Industry (Industry), Utility (Utility), Transportation (Transportation), Banks, savings and loans (Banks) used in the panel data regression covering the crisis period. The variables are monthly values.

\begin{tabular}{|l|c|c|c|c|c|c|c|c|}
\hline & \multicolumn{1}{|c|}{ ff } & \multicolumn{1}{|c|}{ Stoxx } & Return & Value & value & no & Country \\
\hline ff & 1.0000 & & & & & & \\
\hline Stoxx & 0.0350 & 1.0000 & & & & & \\
\hline return & -0.0268 & -0.0945 & 1.0000 & & & & & \\
\hline Value & 0.4869 & 0.1204 & -0.0005 & 1.0000 & & & & \\
\hline value & -0.2913 & 0.0069 & 0.0154 & -0.3957 & 1.0000 & & & \\
\hline no & -0.3205 & -0.0005 & 0.0276 & -0.3905 & 0.9645 & 1.0000 & & \\
\hline Country & 0.1519 & -0.0000 & -0.0435 & 0.0663 & -0.4442 & -0.4395 & 1.0000 & \\
\hline Industry & -0.5241 & 0.0000 & 0.0177 & -0.4568 & 0.1361 & 0.1255 & -0.1242 & 1.0000 \\
\hline Utility & 0.2866 & 0.0000 & -0.0104 & 0.4710 & -0.1089 & -0.0796 & 0.0232 & -0.4148 \\
\hline Transport. & 0.2315 & 0.0000 & -0.0117 & -0.1245 & 0.2161 & 0.2221 & -0.2319 & -0.4148 \\
\hline Banks & 0.2705 & 0.0000 & -0.0117 & 0.5309 & -0.3073 & -0.3123 & 0.3464 & -0.5164 \\
\hline
\end{tabular}

\begin{tabular}{|l|c|c|c|}
\hline & Utility & Transport. & Banks \\
\hline Utility & 1.0000 & & \\
\hline Transport. & -0.0645 & 1.0000 & \\
\hline Banks & -0.0803 & -0.0803 & 1.0000 \\
\hline
\end{tabular}

\section{TABLE 8}

Correlations of the following independent variables: free float of the voting shares $\left(f_{t, n, V}\right)$, Stoxx Europe 600 (Stoxx $x_{t}$, performance of the voting shares (return $\left.{ }_{t, n}\right)$, market value of the company $\left(V_{a l u e}\right)$, relative market value of the non-voting capital (value ${ }_{t, n v}$ ), relative number of the voting shares ( $o_{t, n, N v}$ ), and the dummies for the country (Country), and the sectors Industry (Industry), Utility (Utility), Transportation (Transportation), Banks, savings and loans (Banks) used in the panel data regression covering the boom period. The variables are monthly values.

\begin{tabular}{|l|c|c|c|c|c|c|c|c|}
\hline & \multicolumn{1}{|c|}{ ff } & \multicolumn{1}{c|}{ Stoxx } & Return & Value & Value & no & Country \\
\hline ff & 1.0000 & & & & & & \\
\hline Stoxx & -0.0009 & 1.0000 & & & & & \\
\hline return & -0.0201 & 0.1289 & 1.0000 & & & & & \\
\hline Value & 0.3918 & 0.0415 & 0.0711 & 1.0000 & & & & \\
\hline value & -0.3320 & 0.0067 & -0.0304 & -0.3053 & 1.0000 & & & \\
\hline no & -0.3590 & 0.0013 & 0.0051 & -0.3166 & 0.9674 & 1.0000 & & \\
\hline Country & 0.2849 & 0.0227 & 0.0041 & -0.1365 & -0.4752 & -0.4643 & 1.0000 & \\
\hline Industry & -0.5367 & -0.0151 & -0.0142 & -0.1285 & 0.1347 & 0.1265 & -0.1102 & 1.0000 \\
\hline Utility & 0.3405 & 0.0062 & -0.0508 & 0.1674 & -0.1010 & -0.0826 & 0.0168 & -0.4129 \\
\hline Transport. & -0.0847 & 0.0062 & 0.0050 & -0.1360 & 0.2206 & 0.2282 & -0.2416 & -0.4129 \\
\hline Banks & 0.3505 & 0.0078 & 0.0511 & 0.2950 & -0.3155 & -0.3202 & 0.3428 & -0.5144 \\
\hline
\end{tabular}

\begin{tabular}{|l|c|c|c|}
\hline & Utility & Transport. & Banks \\
\hline Utility & 1.0000 & & \\
\hline Transport. & -0.0665 & 1.0000 & \\
\hline Banks & -0.0828 & -0.0828 & 1.0000 \\
\hline
\end{tabular}




\section{TABLE 9}

Variance inflation factor (VIF) of the following independent variables: free float of the voting shares ( $f f_{t, n}$ ), Stoxx Europe 600 (Stoxx) performance of the voting shares (return $n_{t, y}$ ), market value of the company (Value $e_{t, n}$ ), relative market value of the non-voting capital ( value $_{t, n, N v}$ ), relative number of the voting shares $\left(\right.$ no $\left._{t, n, N v}\right)$, and the dummies for the country (Country), and the sectors Industry (Industry), Utility (Utility), Transportation (Transportation), Banks, savings and loans (Banks) used in the panel data regression covering the crisis and the boom period. The variables are monthly values.

VIF (Crisis)

\begin{tabular}{|l|c|c|}
\hline$f f$ & 1.84 & 2.50 \\
\hline Stoxx & 1.05 & 1.02 \\
\hline return & 1.01 & 1.03 \\
\hline Value & 3.28 & 2.15 \\
\hline value & 1.30 & 1.42 \\
\hline no & 1.65 & 1.68 \\
\hline Country & 1.91 & 2.05 \\
\hline Industry & 4.03 & 2.92 \\
\hline Utility & 2.83 & 2.17 \\
\hline Transport. & 2.02 & 2.20 \\
\hline Banks & 3.76 & $\mathbf{2 . 3 0}$ \\
\hline Mean VIF & $\mathbf{2 . 2 4}$ & \\
\hline
\end{tabular}

\section{TABLE 13}

Correlations of the following independent variables: relative dividend difference ( $\Delta$ dividend ${ }_{T, n}$ ), yearly standard deviation of the monthly free floats of the voting shares (Std_ff $f_{T}$ ), free float of the voting shares ( $f f_{T V}$ ), Stoxx Europe 600 (Stoxx $)$, performance of the voting shares (return $\left.n_{T, V}\right)$, market value of the company (Value $e_{T, n}$ ), relative market value of the non-voting capital (value $e_{T, n, N V}$ ), relative number of the voting shares ( $\mathrm{no}_{T_{n, N v}}$ ), and the dummies for the country (Country), the crisis period (Crisis), the boom period (Boom), and the sectors the Industry (Industry), Utility (Utility), Transportation (Transportation), Banks, savings and loans (Banks) used in the panel data regression covering the entire period. The variables are yearly values.

\begin{tabular}{|c|c|c|c|c|c|c|c|c|}
\hline & $\Delta$ dividend & Std_ff & $F f$ & Stoxx & return & Value & value & no \\
\hline$\Delta$ dividend & 1.0000 & & & & & & & \\
\hline Std_ff & 0.0203 & 1.0000 & & & & & & \\
\hline$f f$ & -0.1491 & 0.0495 & 1.0000 & & & & & \\
\hline Stoxx & -0.0197 & -0.1254 & -0.0075 & 1.0000 & & & & \\
\hline return & -0.0020 & 0.0926 & -0.1056 & -0.0948 & 1.0000 & & & \\
\hline Value & -0.3897 & -0.1191 & 0.5000 & 0.1385 & -0.0906 & 1.0000 & & \\
\hline value & 0.0483 & -0.0202 & -0.4030 & -0.0051 & 0.1442 & -0.3538 & 1.0000 & \\
\hline no & 0.0469 & 0.0166 & -0.4141 & -0.0227 & 0.1596 & -0.3584 & 0.9720 & 1.0000 \\
\hline Country & 0.0334 & -0.0355 & 0.1774 & 0.0083 & -0.1679 & 0.0217 & -0.4460 & -0.4192 \\
\hline Crisis & 0.0409 & -0.1465 & 0.0012 & -0.2733 & -0.3197 & -0.0089 & 0.0030 & 0.0029 \\
\hline Boom & 0.0045 & -0.0522 & -0.0464 & 0.1890 & 0.0815 & -0.0037 & 0.0131 & -0.0003 \\
\hline Industry & 0.2305 & 0.0589 & -0.4247 & -0.0043 & 0.1425 & -0.4081 & 0.1952 & 0.1844 \\
\hline Utility & 0.0196 & -0.0523 & 0.3484 & 0.0169 & -0.084 & 0.4350 & -0.0973 & -0.0826 \\
\hline Transport. & -0.0096 & -0.0213 & 0.0293 & 0.0100 & 0.0107 & -0.1168 & 0.1546 & 0.1687 \\
\hline Banks & -0.3671 & -0.0319 & 0.2664 & -0.0008 & -0.0830 & 0.4337 & -0.3029 & -0.3086 \\
\hline
\end{tabular}

\begin{tabular}{|l|c|c|c|c|c|c|c|}
\hline & Country & Crisis & Boom & Industry & Utility & Transport. & Banks \\
\hline Country & 1.0000 & & & & & & \\
\hline Crisis & -0.0097 & 1.0000 & & & & & \\
\hline Boom & -0.0065 & -0.1540 & 1.0000 & & & & \\
\hline Industry & -0.1655 & -0.0228 & -0.0152 & 1.0000 & & & \\
\hline Utility & 0.0059 & 0.0023 & 0.0015 & -0.4332 & 1.0000 & & \\
\hline Transport. & -0.2159 & 0.0210 & 0.0140 & -0.3992 & -0.0583 & 1.0000 & \\
\hline Banks & 0.3447 & -0.0042 & -0.0028 & -0.5531 & -0.0808 & -0.0744 & 1.0000 \\
\hline
\end{tabular}




\section{TABLE 14}

Variance inflation factor (VIF) of the following independent variables: relative dividend difference ( $\triangle$ dividend ${ }_{T, n}$ ), yearly standard deviation of the monthly free floats of the voting shares $\left(S t d_{-} f f_{T, n, V}\right)$, free float of the voting shares $\left(f f_{T, n, V}\right)$, Stoxx Europe 600 (Stoxx $)_{T}$, performance of the voting shares $\left(\right.$ return $\left._{T, n, V}\right)$, market value of the company $\left(V_{T}\left(u e_{T, n}\right)\right.$, relative market value of the non-voting capital (value $\left.{ }_{T, N, N v}\right)$, relative number of the voting shares (no ${ } n$ ), and the dummies for the country (Country), the crisis period (Crisis), the boom period (Boom), and the sectors the Industry (Industry), Utility (Utility), Transportation (Transportation), Banks, savings and loans (Banks) used in the panel data regression covering the entire period. A second calculation of the variance inflation factor (VIF*) given without the independent factor relative number of voting shares $\left(n o_{I n, N V}\right)$. The variables are yearly values.

\begin{tabular}{|l|c|c|}
\hline & VIF & VIF* \\
\hline$\Delta$ dividend & 1.34 & 1.34 \\
\hline Std_ff & 1.13 & 1.10 \\
\hline ff & 1.68 & 1.64 \\
\hline Stoxx & 1.23 & 1.23 \\
\hline return & 1.25 & 2.59 \\
\hline Value & 2.59 & 1.60 \\
\hline value & 20.03 & 1.59 \\
\hline no & 19.84 & 1.30 \\
\hline Country & 1.62 & 1.06 \\
\hline Crisis & 1.31 & 4.43 \\
\hline Boom & 1.06 & 2.71 \\
\hline Industry & 4.43 & 2.07 \\
\hline Utility & 2.72 & 3.44 \\
\hline Transport. & 2.08 & $\mathbf{1 . 9 5}$ \\
\hline Banks & 3.45 & \\
\hline Mean VIF & $\mathbf{4 . 3 8}$ & \\
\hline
\end{tabular}

